\title{
Prunus africanus Herbal Extracts Reverse and Ameliorate the Histological and Histomorphometric Changes in Testosterone-induced Benign Prostate Hyperplasia Rat Models
}

\author{
Felix P. William* and Denis A. Russa \\ Department of Anatomy and Histology, School of Medicine, Muhimbili University of Health and \\ Allied Sciences, P. O. Box 65001, Dar es Salaam, Tanzania. \\ *Corresponding author. E-mails: peterfelix252@gmail.com; adrussa@yahoo.com \\ Received 9 Apr 2021, Revised 27 Jul 2021, Accepted 30 Jul 2021, Published Aug 2021
}

DOI: https://dx.doi.org/10.4314/tjs.v47i3.27

\begin{abstract}
Benign prostatic hyperplasia (BPH) is the most common benign proliferative disease among men during aging. The herbal extract of $P$. africanus has been used for the treatment of BPH since time immemorial. However microstructural changes of this extract to the prostate of animal or human models are still elusive. Therefore, histological and histomorphometric changes in rats with testosterone-induced BPH due to $P$. africanus herbal extracts were investigated. Twenty-eight male Wistar rats $(200 \pm 50 \mathrm{~g})$ were divided into four groups each with 7 rats. Group 1 (Negative control) was given $2 \mathrm{ml} /$ day of olive oil subcutaneously and $2 \mathrm{ml} /$ day of normal saline intragastrically for 28 days. Three groups were induced with BPH by subcutaneous injection of testosterone propionate $3 \mathrm{mg} / \mathrm{kg}$ body weight/day for 28 days. Thereafter Group 2 (BPH) was sacrificed, while Group 3 (Positive control) and Group 4 (Treatment group) were administered with finasteride $5 \mathrm{mg} / \mathrm{kg} / \mathrm{day}$ and $P$. africanus extract $400 \mathrm{mg} / \mathrm{kg} /$ day intragastrically for 28 days, respectively. BPH group revealed thickening and hyperplasia of tubular epithelium with involutions with the stroma showing large spaces and dilated blood vessels. These features were restored with $P$. africanus extract administration. High epithelial height, large stromal area and lower luminal area observed in the BPH were greatly reversed with $P$. africanus extract comparable to negative controls. Generally, $P$. africanus extract restored and ameliorated histological and histomorphometrical changes of the BPH-induced rat's prostates.
\end{abstract}

Keywords: Benign prostate hyperplasia, Prunus africanus, finasteride, testosterone.

\section{Introduction}

Benign prostatic hyperplasia (BPH) is a histological diagnosis that is associated with an unregulated proliferation of connective tissue stroma and glandular epithelium within the prostatic transition zone (McVary 2006, Auffenberg et al. 2009). According to Barkin et al. (2009), it is a chronic condition that affects aging men predominantly worldwide regardless of their culture or ethnic origins. The incidence of BPH has been shown to increase by $42 \%$ in men between 40 and 50 years and up to $90 \%$ in those over 80 years (McVary 2006, Zhong et al. 2015). The prevalence of clinical BPH in central Tanzania was estimated to be $61.6 \%$ and histologically it was observed as the most common prostatic disease by $60 \%$ (Mwashambwa et al. 2015). Traditionally, the primary goal of BPH treatment has been to alleviate bothersome Lower Urinary Tracts Symptoms (LUTS) that result from prostatic enlargement (McVary 2002, Wilt et al. 2002, Auffenberg et al. 2009). The mainstay management of mild to moderate clinical BPH 
is medical therapy of which different drugs have been used singly or in combination including finasteride, dutasteride, tamsulosin, and prazosin. The most known and common side effects of these agents are erectile dysfunction, loss of libido, ejaculatory dysfunction, gynecomastia, tiredness, dizziness, hip fractures, and occasionally postural hypotension (Auffenberg et al. 2009, Traish 2011). Drug side effects and their high costs lead to decreased compliance and adherence to the medications which tend to reduce the quality of life of patients and increase the burden of the disease (Nichol et al. 2009, Pinto et al. 2015). Alternatively, several herbal medicines that appear to have limited adverse effects have gained increasing popularity in $\mathrm{BPH}$ treatments (Zhong et al. 2015).

Prunus africanus (synonym Pygeum africanus) belongs to the Rosaceae family. It is a widespread evergreen tree, growing at an altitude of $1500-2000 \mathrm{~m}$. It is usually $10-25 \mathrm{~m}$ high with alternate leaves, a straight cylindrical trunk, a dense rounded crown and small white or cream fragrant flowers (Komakech and Kang 2019). It has blackish-brown bark, shining foliage, and greenish or white flowers. It is found in mountains and underlying islands in 22 countries mostly on the eastern side of Africa, it is also found in central Africa (Katanga, Congo), in West Africa, Comoros, and Madagascar. Bark extracts of $P$. africanus are used to treat benign prostate hyperplasia (Thompson et al. 2019). The stem and root bark of $P$. africanus contain many bioactive phytochemicals such as terpenoids, flavonoids, phytosterol, fatty acids, and tannins. The synergistic interactions of these phytochemicals have made $P$. africanus significantly a potent traditional medicine for many diseases and conditions such as benign prostate hyperplasia. It also has anti-cancer, anti-inflammatory, and antiviral effects (Komakech and Kang 2019, Thompson et al. 2019). According to Jena et al. (2016), Pygeum is one of the top-selling herbs in European countries for use as a first-line treatment for the prevention and cure of BPH, and studies conducted in Europe have shown that Pygeum bark is also useful in maintaining a healthy prostate. Numerous clinical trials have demonstrated the clinical usefulness of Pygeum bark in improving LUTS to patients with BPH. In Tanzania, $P$. africanus extract is available as Prucan capsules produced and prescribed by the Institute of Traditional Medicine (ITM) of Muhimbili University of Health and Allied Sciences, Dar es Salaam, Tanzania as an alternative therapy for mild and moderate BPH to patients who are willing to use it, but there are insufficient local studies which support its use. Despite the clinical usefulness of Prunus africanus extracts in amelioration of bothersome LUTS in mild to moderate $\mathrm{BPH}$ and their protective effects in the prostate, the histological and histomorphometric effects of these extracts to the prostate of animal or human models are still elusive. Therefore, this study was designed to investigate the histological and histomorphometric changes to the prostate of rat model with testosterone induced $\mathrm{BPH}$ administered with $P$. africanus extracts.

\section{Materials and Methods \\ Animals}

A total of 28 male Wistar rats $(200 \pm 50 \mathrm{~g})$ three months old were purchased from the animal breeding unit of the Faculty of Veterinary Medicine, Sokoine University of Agriculture, Morogoro Tanzania. Before the start of the experiments, rats were allowed to adapt to the modified conditions for 2 weeks according to Chung et al. (2016). Rats were housed in separate standard aluminium cages and maintained in an air-conditioned room with a 12 hours light/dark cycle, and they were provided with tap water and standard rodent pellets ad libitum.

\section{Experimental design}

All experimental procedures and animal maintenance we conducted following the accepted standards of animal care (Sarkar 2011, Mohr et al. 2016). After the 
acclimatization period of two weeks, rats were randomly divided into four groups each group with 7 rats. Group 1 (negative control group) rats were subcutaneously injected with vehicle agent olive oil $2 \mathrm{ml} /$ day for four weeks and oral normal saline $2 \mathrm{ml} /$ day for four weeks). In Group 2 (BPH group), BPH was induced by subcutaneous injection of testosterone propionate (TP) dissolved in olive oil as a vehicle agent (Testoviron $250 \mathrm{mg}$ ampoule, BM Pharmaceuticals) $3 \mathrm{mg} / \mathrm{kg}$ body weight/day for four weeks and then sacrificed as pathological controls (Ammar et al. 2015, Swaroop et al. 2015). In Group 3 (Treatment group) and Group 4 (positive control group) rats were injected with $\mathrm{TP}$ for four weeks to induce $\mathrm{BPH}$, and after the $\mathrm{BPH}$ induction period, Group 3 (Treatment group) rats were administered with a crude product of $P$. africanus extracts $400 \mathrm{mg} / \mathrm{kg}$ dissolved normal saline $10 \mathrm{ml} / \mathrm{kg}$ daily for four weeks, and Group 4 (positive control group) rats were administered with finasteride (Aurobindo Pharma Ltd) $5 \mathrm{mg} / \mathrm{kg}$ body weight intragastrically for four weeks (Chung et al. 2016)

\section{Preparation and administration of Prunus africanus extract}

Stem barks of $P$. africanus were obtained from the Institute of Traditional Medicine of Muhimbili University of Health and Allied Sciences. They were cleaned, dried, ground and soaked in $98 \%$ of ethanol for three days to ensure complete extraction of the active ingredients by the stated solvent. Thereafter, the solution was filtered by cotton wool followed by concentration of the extract by using a rotary evaporator to obtain the crude extract. Oral administration of the extracts to rats up to $1 \mathrm{~g} / \mathrm{kg}$ body weight daily for 8 weeks does not cause clinical or pathological signs of toxicity (Medicines Agency 2016). According to Jena et al. (2016), most clinical studies on $P$. africanus against $\mathrm{BPH}$ have been carried out at the dose levels of 100 and $200 \mathrm{mg} /$ day in patients, so to obtain an average dose of 100 $\mathrm{mg} /$ day we decided to use a dose of $400 \mathrm{mg} / \mathrm{kg}$ body weight whereby the average weight of the rats was $250 \mathrm{~g}$. The extract powder was dissolved in normal saline and then administered intragastrically; the dose-volume of normal saline used was $10 \mathrm{ml} / \mathrm{kg}$ according to Bloomington Institutional Animal Care and Use Committee (2020).

\section{Sample collection}

At the end of the experimental period, all animals were fasted overnight and euthanized using pentobarbital (Oak Pharmaceuticals, Inc, US) at a dose of $100 \mathrm{mg} / \mathrm{kg}$ body weight injected intraperitoneally (Shin et al. 2012). Ventral prostates were excised, rinsed, and weighed by an analytical balance (Itin Scale Co, Inc. Brooklyn, New York), and then the ratio of the prostate weight to body weight was calculated (prostatic index). The prostatic index (PI) is calculated as PW/BW x 100\% (Zhong et al. 2015).

\section{Histopathological and morphometric study}

Sections of the ventral prostate lobe were fixed in $10 \%$ neutral buffered formalin, then dehydrated in ascending grades of ethanol, cleared in xylene and embedded in liquid paraffin wax. The tissues were sectioned at a thickness of $5 \mu \mathrm{m}$ (Jena et al. 2016) using the Heitz 150 rotary microtome (Cambridge model) to get good contrast, sharpness and easy appreciation of histological details. Sectioned tissues were then subjected to Erlich's Haematoxylin and Eosin ( $\mathrm{H} \& \mathrm{E})$ staining technique using Baker and Silverton method for histological examinations. Histological slides were scanned using the digital slide scanning system Motic Easy Scanner (Motic Incorporation Ltd Hong Kong). There were two investigators; the first investigator read the histological findings and the second measured histomorphometric parameters of the epithelial height, acinar luminal area, and stromal area by using four non-overlapping fields. Both investigators were not aware of the present study (blinded) to reduce observer bias (Nandecha et al. 2010, El-Din and Fattah 2019). All histomorphometric data were 
Tanz. J. Sci. Vol. 47(3) 2021

collected and analyzed using Image J software (Gonzales et al. 2008, El-Din and Fattah 2019).

\section{Data processing and analysis}

Quantitative data were packed and analysed by SPSS statistical software (version 20). All the values of parameters were expressed in mean (M) \pm standard deviation (SD). All continuous data, including the rats' body weight, prostate weight, epithelial height, acinar luminal area, and stroma area were checked for normality using the Shapiro-Wilk test and for homogeneity of variance using Equal Variance Test. Data of different groups were analysed using one-way analysis of variance (ANOVA), followed by Tukey's post hoc test. The data showing significance in their variances were subjected to Dunnett's T3 test. A value of $p<$ 0.05 was considered statistically significant. Other histological findings were described accordingly.

\section{Ethical clearance}

The study was carried out after ethical clearance approval from the Ethical Committee of Muhimbili University of Health and Allied
Sciences letter with Ref. No. DA.287/298/01A/.

\section{Results}

A Shapiro-Wilk test $(p>0.05)$ (Table 1), (Shapiro and Wilk 1965, Razali and Wah 2011) and a visual inspection of histogram, normal Q$\mathrm{Q}$ plots and Box plot showed that prostate weights were approximately normally distributed for all the animal groups, with skewness of $-0.3259(\mathrm{SE}=1.014)$ and kurtosis of 1.014 ( $\mathrm{SE}=2.619$ ) for Negative control, skewness of $1.485(\mathrm{SE}=1.014)$ and kurtosis of $2.204(\mathrm{SE}=2.619)$ for $\mathrm{BPH}$, skewness of $0.615(\mathrm{SE}=1.014)$ and kurtosis of 0.460 (SE $=2.619)$, skewness of $0.005(\mathrm{SE}=1.014)$ and kurtosis of $-5.787(\mathrm{SE}=2.619)$. Prostate weight of BPH group was numerically higher $(n=4$, $M=866.50, S D=63.98)$ than the negative control group ( $n=4$, Mean or $M=418.50$, Standard deviation or $S D=9.04)$. Treatment group $(n=4, M=490.03, S D=6.03)$ and positive control group ( $n=4, M=447.75, S D$ $=51.28)$ had lower weights compared to the BPH group $(n=4, M=866.50, S D=63.98)$ (Table 1).

Table 1: Prostate weight $(\mathrm{mg})$ of rats and their Normality test $(N=24)$

\begin{tabular}{|c|c|c|c|c|c|c|c|c|}
\hline \multirow[b]{2}{*}{ Group } & \multirow[b]{2}{*}{$\mathrm{n}$} & \multirow[b]{2}{*}{ Mean } & \multirow[b]{2}{*}{$\begin{array}{l}\text { Standard } \\
\text { deviation }\end{array}$} & \multicolumn{2}{|c|}{$\begin{array}{l}95 \% \text { Confidence } \\
\text { Interval for Mean }\end{array}$} & \multicolumn{3}{|c|}{ Shapiro-Wilk } \\
\hline & & & & $\begin{array}{l}\text { Lower } \\
\text { bound }\end{array}$ & $\begin{array}{l}\text { Upper } \\
\text { bound }\end{array}$ & Statistic & Df & $\begin{array}{c}p- \\
\text { value }\end{array}$ \\
\hline $\begin{array}{l}\text { Negative } \\
\text { control }\end{array}$ & 4 & 418.50 & 9.04 & 404.12 & 432.88 & 0.975 & 4 & 0.870 \\
\hline $\mathrm{BPH}$ & 4 & 866.50 & 63.98 & 764.69 & 968.31 & 0.874 & 4 & 0.315 \\
\hline Treatment & 4 & 490.03 & 6.03 & 480.43 & 499.62 & 0.983 & 4 & 0.919 \\
\hline $\begin{array}{l}\text { Positive } \\
\text { control }\end{array}$ & 4 & 447.75 & 51.28 & 366.15 & 529.35 & 0.800 & 4 & 0.103 \\
\hline
\end{tabular}

Note: value is statistically significant at $p<0.05, \mathrm{Df}=$ Degrees of freedom.

A visual inspection of rats weight's histogram, normal Q-Q plots and Box plot and a Shapiro-Wilk test $(p<0.05)$ showed approximately a normal distribution for all animal groups (Table 2), with skewness of $0.203(\mathrm{SE}=1.014)$ and kurtosis of $-4.776(\mathrm{SE}$ $=2.619$ ) for the negative control, skewness of -
$0.975(\mathrm{SE}=1.014)$ and kurtosis of $1.285(\mathrm{SE}=$ 2.619) for $\mathrm{BPH}$, skewness of 1.049 ( $\mathrm{SE}=$ $1.014)$ and kurtosis of $0.761(\mathrm{SE}=2.619)$ for treatment and skewness of $0.462(\mathrm{SE}=1.014)$ and kurtosis of $-1.082(\mathrm{SE}=2.619)$ for positive control. 
William and Russa - Prunus africanus Herbal Extracts Reverse and Ameliorate the Histological ...

Table 2: Weight of rats $(\mathrm{g})$ and their Normality test $(N=24)$

\begin{tabular}{|c|c|c|c|c|c|c|c|c|}
\hline \multirow[b]{2}{*}{ Group } & \multirow[b]{2}{*}{$\mathrm{n}$} & \multirow[b]{2}{*}{ Mean } & \multirow[b]{2}{*}{$\begin{array}{l}\text { Standard } \\
\text { deviation }\end{array}$} & \multicolumn{2}{|c|}{$\begin{array}{l}95 \% \text { Confidence } \\
\text { Interval for Mean }\end{array}$} & \multicolumn{3}{|c|}{ Shapiro-Wilk } \\
\hline & & & & $\begin{array}{l}\text { Lower } \\
\text { bound }\end{array}$ & $\begin{array}{l}\text { Upper } \\
\text { bound }\end{array}$ & Statistic & Df & $\begin{array}{c}\mathrm{p}- \\
\text { value }\end{array}$ \\
\hline $\begin{array}{l}\text { Negative } \\
\text { control }\end{array}$ & 4 & 225.25 & 12.09 & 206.01 & 244.49 & 0.851 & 4 & 0.229 \\
\hline $\mathrm{BPH}$ & 4 & 223.50 & 16.54 & 197.18 & 249.82 & 0.953 & 4 & 0.733 \\
\hline Treatment & 4 & 224.00 & 11.75 & 205.31 & 242.69 & 0.939 & 4 & 0.650 \\
\hline $\begin{array}{l}\text { Positive } \\
\text { control }\end{array}$ & 4 & 223.25 & 12.61 & 203.19 & 243.30 & 0.978 & 4 & 0.891 \\
\hline
\end{tabular}

Note: value is statistically significant at $p<0.05$.

Relative prostate weight (prostate/body weight ratio) of rats between groups showed that the $\mathrm{BPH}$ group was heavier (3.81) compared to the negative control (1.86), treatment (2.19) and positive control (2.02) (Figure 1).

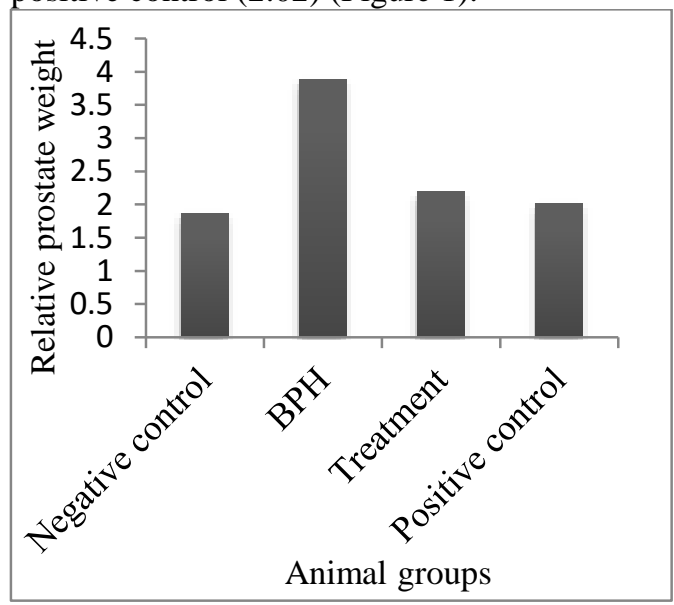

Figure 1: Relative prostate weight of rats.

The distribution of epithelial height, acinar luminal area and stroma area across different animal groups was approximately normal by a visual inspection of their histogram, normal Q$\mathrm{Q}$ plots and Box plot with skewness and Kurtosis as shown in Table 3, but also a Shapiro-Wilk test for normality was not significant $(p>0.05)$ (Table 3$)$.

Epithelial height was higher in the BPH group ( $n=4, M=27.15, S D 0.97)$ than in negative control $(n=4, M=16.14, S D=0.37)$, positive control $(n=4, M=16.55, S D=0.48)$ and in treatment group $(n=4, M=17.10, S D=$ 0.32). BPH group had a small acinar luminal area $(n=4, M=299.50, S D=1.29)$ compared to negative control $(n=4, M=348.50, S D=$ 1.29), positive control $(n=4, M=349.90, S D$ =1.67), and treatment group $(n=4, M=$ $350.22, S D=1.10)$. Stroma area of the BPH group was larger $(n=4, M=341.13, S D=$ 1.26) from that of normal control $(n=4, M=$ $246.13, S D=1.09)$, positive control $(n=4, M$ $=247.21, S D=0.32)$ and treatment group $(n=$ 4, $M=248.28, S D=0.49)$ (Table 4). 
Tanz. J. Sci. Vol. 47(3) 2021

Table 3: Normality and distribution of epithelial height, acinar luminal area and stroma area

\begin{tabular}{lllllllll}
\hline \multirow{2}{*}{ Group } & & & & & & \multicolumn{3}{c}{ Shapiro-Wilk Test } \\
\cline { 6 - 8 } & Parameters & Skewness & Std & Kurtosis & Std & Statistic & df & \multirow{2}{*}{ Sig. } \\
\hline \multirow{2}{*}{ Negative C } & Epithelial H & 0.122 & 1.014 & 1.475 & 2.619 & 0.958 & 4 & 0.769 \\
& Acinar L & 0.000 & 1.014 & -1.200 & 2.619 & 0.993 & 4 & 0.972 \\
& Stroma area & -0.442 & 1.014 & -2.396 & 2.619 & 0.946 & 4 & 0.694 \\
BPH & Epithelial H & 0.812 & 1.014 & -1.260 & 2.619 & 0.958 & 4 & 0.769 \\
& Acinar L & 0.000 & 1.014 & -1.200 & 2.619 & 0.993 & 4 & 0.972 \\
\multirow{5}{*}{ Treatment } & Stroma area & -0.826 & 1.014 & 0.602 & 2.619 & 0.946 & 4 & 0.694 \\
& Epithelial H & 0.632 & 1.014 & -1.700 & 2.619 & 0.958 & 4 & 0.769 \\
& Acinar L & 0.125 & 1.014 & -2.196 & 2.619 & 0.993 & 4 & 0.972 \\
Positive C & Stroma area & 1.223 & 1.014 & 1.085 & 2.619 & 0.946 & 4 & 0.694 \\
& Epithelial H & -0.290 & 1.014 & -3.958 & 2.619 & 0.958 & 4 & 0.769 \\
& Acinar L & 0.085 & 1.014 & -4.307 & 2.619 & 0.993 & 4 & 0.972 \\
& Stroma area & 0.453 & 1.014 & -2.643 & 2.619 & 0.946 & 4 & 0.694 \\
\hline
\end{tabular}

Note; $\mathrm{C}=$ Control, $\mathrm{H}=$ Height, $\mathrm{L}=$ Luminal, $\mathrm{Std}=$ standard, value is significant at $\mathrm{p}<0.05$.

Table 4: Distribution of epithelial height, acinar luminal area and stroma area in different group $(N=24)$

\begin{tabular}{|c|c|c|c|c|c|c|}
\hline \multirow[b]{2}{*}{ Parameters } & \multirow[b]{2}{*}{ Group } & \multirow[b]{2}{*}{$\mathrm{n}$} & \multirow[b]{2}{*}{ Mean } & \multirow[b]{2}{*}{$\begin{array}{l}\text { Std. } \\
\text { deviation }\end{array}$} & \multicolumn{2}{|c|}{$\begin{array}{l}95 \% \text { Confidence interval } \\
\text { for mean }\end{array}$} \\
\hline & & & & & $\begin{array}{l}\text { Lower } \\
\text { bound }\end{array}$ & $\begin{array}{l}\text { Upper } \\
\text { bound }\end{array}$ \\
\hline \multirow{4}{*}{$\begin{array}{l}\text { Epithelia } \mathrm{H} \\
{[\mu \mathrm{m}]}\end{array}$} & Negative C & 4 & 16.14 & 0.37 & 15.56 & 16.73 \\
\hline & BPH & 4 & 27.15 & 0.97 & 25.61 & 28.68 \\
\hline & Treatment & 4 & 17.10 & 0.32 & 16.60 & 17.60 \\
\hline & Positive C & 4 & 16.55 & 0.48 & 15.79 & 17.31 \\
\hline \multirow{4}{*}{$\begin{array}{l}\text { Acinar } \\
\text { lumen } \\
{\left[\mu \mathrm{m}^{2}\right]}\end{array}$} & Negative C & 4 & 348.50 & 1.29 & 346.45 & 350.55 \\
\hline & BPH & 4 & 299.50 & 1.29 & 297.45 & 301.55 \\
\hline & Treatment & 4 & 350.22 & 1.10 & 348.46 & 351.98 \\
\hline & Positive C & 4 & 349.90 & 1.67 & 347.25 & 352.55 \\
\hline \multirow{4}{*}{$\begin{array}{l}\text { Stroma } \\
\text { area } \\
{\left[\mu \mathrm{m}^{2}\right] \times 10^{3}}\end{array}$} & Negative C & 4 & 246.13 & 1.09 & 244.39 & 247.86 \\
\hline & $\mathrm{BPH}$ & 4 & 341.13 & 1.26 & 339.12 & 343.13 \\
\hline & Treatment & 4 & 248.28 & 0.49 & 247.49 & 249.06 \\
\hline & Positive C & 4 & 247.21 & 0.32 & 246.70 & 247.72 \\
\hline
\end{tabular}

Note: $\mathrm{C}=$ Control, $\mathrm{H}=$ Height, $\mathrm{Std}=$ Standard.

Table 5: Test of homogeneity of variances

\begin{tabular}{lcccc}
\hline & Levene statistic & df1 & df2 & Sig. \\
\hline Epithelia height & 4.134 & 5 & 18 & 0.011 \\
Acinar lumen & 1.659 & 5 & 18 & 0.196 \\
Stroma area & 9.829 & 5 & 18 & 0.000 \\
\hline
\end{tabular}

Note: value is significant at $p<0.05$.

Levene's test indicated significant differences for epithelial height $(p=0.011)$ and stroma area $(p=0.000)$ and no significant differences for the acinar luminal area $(p=$ 
0.196) (Table 5), thus the null hypothesis of equal variance was rejected for the dependent variables of epithelial height and stroma area but accepted for the acinar luminal area.

The ANOVA results showed that the mean values differed significantly among different animal groups for epithelial height $\left(F_{5,18}=\right.$ $314.28, p=0.001)$, acinar luminal area $\left(F_{5,18}\right.$ $=1150.24, p=0.000)$ and stroma area $\left(F_{5,18}=\right.$ $10910.95, p=0.000)$. Therefore, to check for the individual differences between groups, post hoc comparisons were performed whereby Dunnett's T3 test was selected for dependent variables of epithelial height and stroma area because equal variance was not assumed, while for the acinar luminal area, Tukey's HSD post hoc test was selected since equal variance was assumed (Swaroop et al. 2015, Lee and Lee
2018). The test indicated that the mean epithelial heights differed significantly between groups, with BPH having higher epithelial height than the negative control group ( $p=$ $0.000)$, positive control group $(p=0.000)$ and treatment group ( $p=0.001)$ (Table 6). There was a statistical significant difference between groups for the mean acinar luminal area with $\mathrm{BPH}$ having a smaller luminal area than the negative control group $(p=0.000)$, positive control group $(p=0.000)$ and treatment group $(p=0.000)$ (Table 6). Mean stroma area distribution between groups was significantly different with the BPH group having a larger stroma area compared to negative control $(p=$ $0.000)$, positive control group $(p=0.000)$ and treatment group $(p=0.000)$ (Table 6).

Table 6: Multiple comparisons of dependent variable between individual group with Dunnett's T3 test

\begin{tabular}{|c|c|c|c|c|c|c|c|}
\hline \multirow[t]{2}{*}{ Parameter } & \multirow{2}{*}{$\begin{array}{l}\text { Group } \\
\text { (I) }\end{array}$} & \multirow[t]{2}{*}{ Group (J) } & \multirow{2}{*}{$\begin{array}{l}\text { MD (I- } \\
\mathrm{J})\end{array}$} & \multirow{2}{*}{$\begin{array}{l}\text { Std. } \\
\text { Error }\end{array}$} & \multirow[t]{2}{*}{ Sig. } & \multicolumn{2}{|c|}{$95 \%$ Confidence Interval } \\
\hline & & & & & & $\begin{array}{l}\text { Lower } \\
\text { bound }\end{array}$ & $\begin{array}{l}\text { Upper } \\
\text { bound }\end{array}$ \\
\hline \multirow{3}{*}{$\begin{array}{l}\text { Epithelial } \\
\text { height }\end{array}$} & \multirow{3}{*}{$\mathrm{BPH}$} & Negative $\mathrm{C}$ & $11.00^{*}$ & 0.52 & 0.000 & 8.27 & 13.73 \\
\hline & & Positive C & $10.10^{*}$ & 0.54 & 0.000 & 7.95 & 13.24 \\
\hline & & Treatment & $10.05^{*}$ & 0.51 & 0.001 & 7.27 & 12.82 \\
\hline \multirow{4}{*}{$\begin{array}{l}\text { Acinar } \\
\text { lumen }\end{array}$} & \multirow{3}{*}{$\mathrm{BPH}$} & Negative $\mathrm{C}$ & $-49.00^{*}$ & 0.85 & 0.000 & -51.70 & -46.31 \\
\hline & & Positive C & $-50.40^{*}$ & 0.85 & 0.000 & -53.09 & -47.71 \\
\hline & & Treatment & $-50.72^{*}$ & 0.85 & 0.000 & -53.40 & -48.03 \\
\hline & \multirow{3}{*}{$\mathrm{BPH}$} & Negative $\mathrm{C}$ & $95.00^{*}$ & 0.83 & 0.000 & 91.42 & 98.58 \\
\hline \multirow[t]{2}{*}{ Stroma area } & & Positive $\mathrm{C}$ & $93.92^{*}$ & 0.65 & 0.000 & 90.20 & 97.63 \\
\hline & & Treatment & $92.85^{*}$ & 0.68 & 0.000 & 89.30 & 96.39 \\
\hline
\end{tabular}

Figure 2 shows the histological changes to the prostate of rats between animal groups. In the control group, normal prostate histology is visible showing tubules with normal epithelia and lumens are filled with prostatic secretions. The connective tissue stroma has normal spaces and blood vessels (Figure 2A). BPH group reveals thickening of tubules epithelium and every tubule almost has developed large involutions projecting into the lumen reducing the volume of the lumen, while the connective tissue stroma showed large spaces and dilated blood vessels (Figure 2B). The positive control group (Figure 2C) and treatment group (Figure 2D) showed marked improvements and restoration of many histological features comparable to the normal prostatic characteristics of the negative control in the form of reduced acinar epithelium thickness with absent involutions and decreased stromal spaces. 


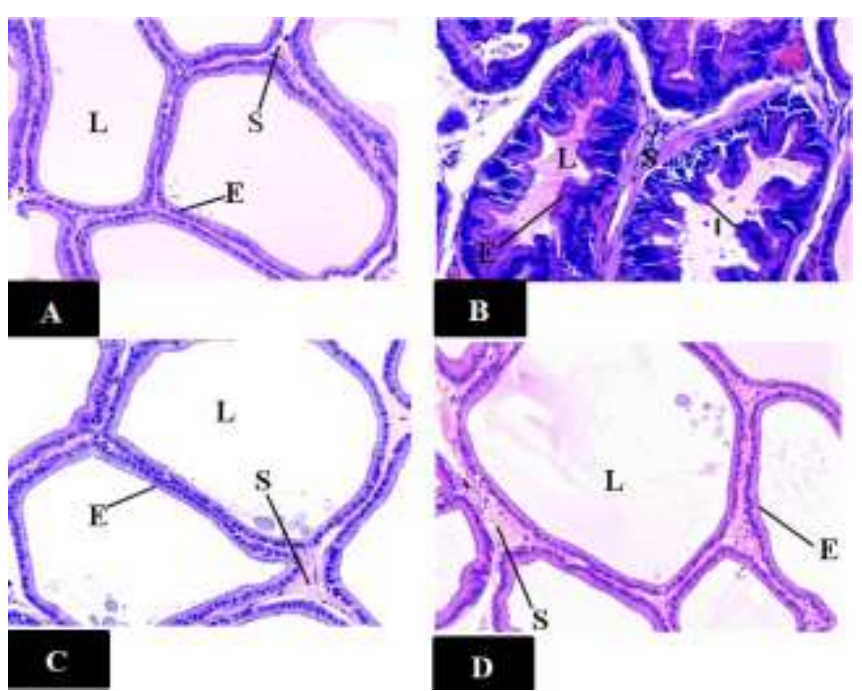

Figure 2: Photomicrographs of the prostate tissues between groups, HE-stained $(\times 40)(\mathrm{A})$ Negative control group; (B) BPH group; (C) Positive control (D) Treatment group; E = Epithelial; $\mathrm{I}=$ Involution; $\mathrm{L}=$ Lumen; and $\mathrm{S}=$ Stroma.

\section{Discussion}

This study aimed to investigate the histological and histomorphometric changes of Prunus africanus extracts to rats with testosterone-induced BPH. It was found that the altered histological features and abnormal histomorphometric parameters caused by testosterone-induced BPH were reversed and ameliorated in the treatment and positive control group comparable to that of the negative control group. The prostate weight for the $\mathrm{BPH}$ group in the present study increased significantly compared to that of the negative control. This indicated the successfulness of the $\mathrm{BPH}$ induction in the present study by using testosterone propionate as has been reported previously by Agrawal et al. (2012) and Swaroop et al. (2015). The decrease of prostate weight in the positive control and treatment group shows grossly how finasteride and $P$. africanus extracts, respectively counteracted $\mathrm{BPH}$ activity in the prostate. The anti-BPH activities of the $P$. africanus extracts and finasteride are known, and they have been used as medical therapies in the management of LUTS/ BPH (Auffenberg et al 2009, Hutchison et al. 2007).
Histologically, the findings of the present study have demonstrated prostate hyperplastic activity in the BPH group as has been reported also previously by El-Din and Fattah (2019). Dihydrotestosterone (DHT), a primary metabolite of testosterone, plays a key role in hyperplastic prostatic growth. The conversion of testosterone to DHT is mediated by the enzyme $5 \alpha$-reductase located in the prostate (Anderson et al. 2001). Spaces within the connective tissues of the prostate contain components like fibres, cells, blood vessels and smooth muscles (Peehl and Sellers 1997). The fibres were not seen clearly in the present study, but cigar-shaped nuclei of smooth muscles can be seen. Dilated blood vessels in the BPH group showed increased activity in the connective tissue stroma due to hyperplasia; therefore, large spaces within the connective tissue of the prostate indicated the unregulated proliferation of its components associated with testosterone injection (Auffenberg et al. 2009). The treatment and positive control groups showed restoration of histological features. This is attributed to the fact that finasteride and $P$. africunus extract are among 5-alpha reductase inhibitors that inhibit the conversion 
of testosterone to dihydrotesterone (DHT) in the prostate (Hutchison et al. 2007 Pagano et al. 2014), and by reducing the production of DHT it will suppress the hyperplastic activity of the epithelium and stroma components. The restorations of histopathological changes in the prostate of rats induced with $\mathrm{BPH}$ are consistent with the findings of Komakech and Kang (2019).

The histomorphometric data of the present study showed an increase in the epithelial height of the BPH group because testosterone injection for four weeks does cause hyperplasia of the epithelial cells (El-Din and Fattah 2019), which increases their thickness and height. The positive control and treatment group had an epithelial height approximately close to that of the negative control, and this finding is consistent with that of Shin et al. (2012). The significant reduction of the mean acinar luminal area in the BPH group compared with that of the negative control has been also reported by Agrawalet al. (2011), and it is due to the projection of thickened epithelial cells into the lumen of the prostatic tubules. However, in the treatment and positive control groups, the acinar luminal area increased resembling that of the negative control, and this happened because the administration of finasteride and $P$. africanus extracts suppressed the uncontrolled proliferation of the epithelial cells, therefore epithelial involutions diminished (Chung et al. 2016). Prostatic stroma is composed of two predominant types of cells, fibroblasts and smooth muscle cells but it also contains androgen receptors (Peehl and Sellers 1997); all these tend to play part in the expansion of the stroma for the different pathological mechanism underlying $\mathrm{BPH}$ like androgen hormone (Zhong et al. 2015). Pathologically, BPH is characterized by an increase in the number of stromal cells (Pagano et al. 2014) as we observed in the BPH group compared with the other groups. El-Din and Fattah (2019) also showed stromal expansion with marked collagen deposition in the connective tissue stroma of the BPH-induced prostate. The significantly lower stroma areas in the treatment and positive control group compared with BPH showed how finasteride and $P$. africanus extracts reversed the hyperplastic activities in the connective tissue stroma.

To the best of our knowledge, this is the first study to show histomorphometric changes associated with $P$. africanus extracts in rat models. In our local settings, some patients with mild to moderate $\mathrm{BPH}$ have been using $P$. africanus extracts in a special formulation named Prucan capsules as an alternative to medical therapy, and they do report to improve Lower Urinary Tracts Symptoms (LUTS) of $\mathrm{BPH}$. This potential is also supported in the literature by Breza et al. (1998), Ishani et al. (2000) and Pagano et al. (2014). In European countries, phytotherapy has been used as the first-line treatment for mild-to-moderate LUTS and represents about $90 \%$ of all the drugs that are prescribed for the treatment of $\mathrm{BPH}$ (Medicines Agency 2016), therefore, the findings of the present study supplement histological effects and also adds histomorphometric effects of $P$. africanus extracts to what is already known about usefulness and efficacy of these extracts in the clinical management of BPH (Emmanuel 2010, Kipkore et al. 2014, Komakech and Kang 2019). Therefore, it scientifically plausible to recommend the use of $P$. africanus extracts in our local settings as the alternative or one of the treatment options for mild to moderate $\mathrm{BPH}$.

\section{Conclusion}

This study has demonstrated that $P$. africanus extracts reversed and ameliorated the histological and histomorphometric changes of the prostate in the BPH-induced rat model. The present study employed routine histological staining methods which may not succinctly elucidate subtle microstructures of the prostate tissue. Further studies employing newer and robust methods may be needed to appreciate fine histological features of the prostate with the administration of multiple doses of $P$. 
africanus extracts in the rat model and later in the human prostate.

\section{Acknowledgement}

We acknowledge the contributions of the Institute of Traditional Medicine (ITM) of Muhimbili University of Health and Allied Sciences (MUHAS) in the present study.

Conflict of Interests: There are no conflicts of interest associated with this publication and there has been no significant financial support for this work that could have influenced its outcome.

\section{References}

Agrawal M, Nahata A and Dixit VK 2012 Protective effects of Echinops echinatus on testosterone-induced prostatic hyperplasia in rats. Eur. J. Integr. Med. 4(2): 177-185.

Anderson JB, Roehrborn CG, Schalken JA and Emberton M 2001 The progression of benign prostatic hyperplasia: Examining the evidence and determining the risk Eur. Urol. 39(4): 390399.

Ammar AE, Esmat A, Hassona MDH, Tadros MG, Abdel-Naim AB and Guns EST 2015 The effect of pomegranate fruit extract on testosterone-induced $\mathrm{BPH}$ in rats. Prostate 75(7): 679-692.

Auffenberg GB, Helfand BT and McVary KT 2009 Established medical therapy for benign prostatic hyperplasia. Urol. Clin. North Am. 36(4): 443-459.

Barkin J, Roehrborn CG, Siami P, Haillot O, Morrill B, Black L and Montorsi F 2009 Effect of dutasteride, tamsulosin and the combination on patient-reported quality of life and treatment satisfaction in men with moderate-to-severe benign prostatic hyperplasia: 2-year data from the CombAT trial. BJU Int. 103(7): 919-926.

Breza J, Dzurny O, Borowka A, Hanus T, Petrik R, Blane G, Chadha-Boreham H, Autet W 1998 Efficacy and acceptability of Tadenan ${ }^{\circledR}$ (Pygeum africanum extract) in the treatment of benign prostatic hyperplasia (BPH): A multicentre trial in central Europe. Curr. Med. Res. Opin. 14(3): 127-139.
Bloomington Institutional Animal Care and Use Committee 2020 'IACUC Policy for Dose Volumes in Laboratory Animals: 1-7.

Chung KS, Shin SJ, Lee NY, Cheon SY, Park W, Sun SH and An HJ 2016 Anti-proliferation effects of garlic (Allium sativum L.) on the progression of benign prostatic hyperplasia. Phytother. Res. 30(7): 1197-1203.

El-Din WAN and Fattah IOA 2019 The potential curative and preventive effects of garlic on testosterone-induced benign prostatic hyperplasia in orchiectomized rats. Rom. J. Morphol. Embryol. 60(1): 145-158.

Emmanuel N 2010 Ethno medicines used for treatment of prostatic disease in Foumban, Cameroon. Afr. J. Pharm. Pharmacol. 4(11): 793-805.

Gonzales GF, Gasco M, Malheiros-Pereira A and Gonzales-Castañeda C 2008 Antagonistic effect of Lepidium meyenii (red maca) on prostatic hyperplasia in adult mice. Andrologia 40(3): 179-185.

Hutchison A, Farmer R, Verhamme K and Berges R 2007 The efficacy of drugs for the treatment of LUTS/BPH, a study in 6 European countries. Eur. Urol. 51: 207-216.

Ishani A, MacDonald R, Nelson D, Rutks I and Wilt TJ 2000 Pygeum africanum for the treatment of patients with benign prostatic hyperplasia: a systematic review and quantitative meta-analysis. Am. J. Med. 109(8): 654-664.

Jena AK, Vasisht K, Sharma N, Kaur R, Dhingra MS and Karan M 2016 Amelioration of testosterone-induced benign prostatic hyperplasia by Prunus species. $J$. Ethnopharmacol. 190: 33-45.

Kipkore W, Wanjohi B, Rono $\mathrm{H}$ and Kigen $\mathrm{G}$ 2014 A study of the medicinal plants used by the Marakwet Community in Kenya. $J$. Ethnobiol. Ethnomed. 10(1): 1-22.

Komakech R and Kang Y 2019 Ethnopharmacological potential of African cherry [Prunus africana]. J. Herbal Med. 17: 100283.

Lee S and Lee DK 2018 What is the proper way to apply the multiple comparison test?. Korean J. Anesthesiol. 71(5): 353-360.

Mckelvie GB, Collins GN, Hehir M, Rogers CAN 1993 A study of benign prostatic hyperplasia-a 
challenge to British urology. British J. Urol. 71(1): 38-42.

McVary KT 2002 Medical therapy for benign prostatic hyperplasia progression. Curr. Urol. Rep. 3(4): 269-275.

McVary KT 2006 BPH: epidemiology and comorbidities. Am. J. Manag. Care 12(5 Suppl): S122-8.

Medicines Agency E 2016 Assessment report on Prunus africana (Hook f.) Kalkm., cortex.44 (July).

Mohr BJ, Fakoya FA, Hau J, Souilem O and Anestidou L 2016.The governance of animal care and use for scientific purposes in Africa and the middle east. ILAR J. 57(3): 333-346.

Mwashambwa MY, Lilungulu AG, Meremo AJ, Gesase AP and House M 2015 Retrospective review of the clinical and pathological pattern of prostatic diseases: a reminder to clinicians on an increased clinical vigilance, an experience from central, Tanzania. Tanzania Med. J. 27(1): 70-82.

Nandecha C, Nahata A and Dixit VK 2010 Effect of Benincasa hispida fruits on testosteroneinduced prostatic hypertrophy in albino rats Curr. Therap. Res.-Clin. Exp. 71(5): 331-343.

Nichol MB, Knight TK, Wu J, Barron R and Penson DF 2009 Evaluating use patterns of and adherence to medications for benign prostatic hyperplasia. J. Urol. 181(5): 2214-2222.

Pagano E, Laudato M, Griffo M and Capasso R 2014 Phytotherapy of benign prostatic hyperplasia. A mini review. Phytother. Res. 28(7): 949-955.

Peehl DM and Sellers RG 1997 Induction of smooth muscle cell phenotype in cultured human prostatic stromal cells. Exp. Cell Res. 232(2): 208-215.

Pinto JDO, He HG, Chan, SWC, Toh PC, Esuvaranathan K and Wang 2015 Healthrelated quality of life and psychological well- being in patients with benign prostatic hyperplasia. J. Clin. Nurs. 24(3-4): 511-522.

Razali NM and Wah YB 2011 Power comparisons of Shapiro-Wilk, KolmogorovSmirnov, Lilliefors and Anderson-Darling tests. J. Stat. Model. Anal. 2(1): 21-33.

Sarkar J 2011 The animal welfare act. Curr. Sci. 101(10): 1268-1268.

Shapiro ASS and Wilk MB 1965 An Analysis of variance test for normality (complete samples): Biometrika 52(3/4): 591-611.

Shin IS, Lee MY, Ha HK, Seo CS and Shin HK 2012 Inhibitory effect of Yukmijihwang-tang, a traditional herbal formula against testosteroneinduced benign prostatic hyperplasia in rats. BMC Complement. Altern. Med. 12: 48.

Swaroop A, Bagchi M, Kumar P, Preuss HG and Bagchi D 2015 Safety and efficacy of a novel Prunus domestica extract (Sitoprin, CR002) on testosterone-induced benign prostatic hyperplasia (BPH) in male Wistar rats. Toxicol. Mechan. Methods 25(9): 653-664.

Thompson RQ, Katz D and Sheehann B 2019 Chemical comparison of Prunus africana bark and pygeum products marketed for prostate health. J. Pharm. Biomed. Anal. 163: 162-169.

Traish AM, Hassani J, Guay AT, Zitzmann M and Hansen ML 2011 Adverse side effects of $5 \alpha$ reductase inhibitors therapy: Persistent diminished libido and erectile dysfunction and depression in a subset of patients. J. Sex. Med. 8(3): 872-884.

Wilt TJ, Howe W and MacDonald R 2002 Terazosin for treating symptomatic benign prostatic obstruction: A systematic review of efficacy and adverse effects. BJU Int. 89(3): 214-225.

Zhong X, Lin J, Zhou J, Xu W and Hong Z 2015 Anti-proliferative effects of qianliening capsules on prostatic hyperplasia in vitro and in vivo. Mol. Med. Rep. 12(2): 1699-1708. 